\title{
Seasonal variation in groundfish habitat associations in the Gulf of Maine-Georges Bank region
}

\author{
Elizabeth T. Methratta ${ }^{1,2, *}$, Jason S. Link ${ }^{1}$ \\ ${ }^{1}$ National Marine Fisheries Service, Northeast Fisheries Science Center, Food Web Dynamics Program, 166 Water Street, \\ Woods Hole, Massachusetts 02540, USA \\ ${ }^{2}$ Present address: Department of Biology, University of Pennsylvania, 415 S. University Avenue, Philadelphia, \\ Pennsylvania 19104, USA
}

\begin{abstract}
Fish distributions are related to several habitat factors. We explored how the distribution of a 24 species assemblage is related to depth, temperature, substrate, season, and time-block using a $35 \mathrm{yr}$ time series in the Gulf of Maine-Georges Bank region. We examined the relative importance of each factor, how it changes with season, and how individual species shift their relative distribution along environmental gradients on a seasonal basis. Distribution patterns were more strongly related to depth and temperature than to substrate type in both fall and spring. We observed 4 major patterns: (1) some species remained in relatively deep waters in both fall and spring; (2) some remained in relatively shallow habitats in both seasons and experienced wide temperature fluctuations as a result; (3) some moved from warmer shallow areas in the fall to warmer deep areas in the spring; (4) some traveled from the cool deep portion of the region in the fall to the cool shallow portion of the region in the spring. Of the 24 species examined, 19 declined in biomass over the study period in response to exploitation. The relationships between abundance and substrate type previously established for some species at local scales were weak at more synoptic spatial scales, although some trends in substrate associations were observed. Defining habitat at broad spatial scales remains a unique challenge. Compared to temperate systems, more refined habitat delineations for demersal marine fish have been established in tropical coral reef systems. Accordingly, much of our theory and the methodologies for applied spatial management have been derived from tropical systems. Differences between temperate and tropical systems necessitate modified approaches for temperate systems.
\end{abstract}

KEY WORDS: Demersal fish · Temperate · Grain size · Essential fish habitat - Spatial fisheries management

\section{INTRODUCTION}

The distribution and abundance of marine fish are influenced by a variety of factors. Establishing associations between fish and their environment enhances our knowledge of how environmental fluctuations influence fish distributions and can ultimately improve our ability to manage natural marine resources. Most studies exploring the roles of environmental variables at broad scales have found species distributions to be strongly related to depth and temperature (e.g. Over- holtz \& Tyler 1985, Murawski \& Finn 1988, Gabriel 1992, Perry \& Smith 1994). Depth is important for the distribution of prey, migratory patterns, and life history strategies (e.g. Grosslein \& Azarovitz 1982). Variation in the thermal environment affects the rates of physiological processes (e.g. Jobling 2002) and for many species the tolerable thermal range is well known (e.g. Grosslein \& Azarovitz 1982, Collette \& Klein-MacPhee 2002). Because temperature at depth varies seasonally on the NE US Shelf (Drinkwater \& Mountain 1997), the depth and temperature preferences of thermally sensi- 
tive species may shift on a seasonal basis (Murawski \& Finn 1988, Perry \& Smith 1994). In marine ecosystems, depth, temperature and the seasonal variation in these 2 factors can influence fish populations and merit examination.

Most studies identifying strong associations of fish abundance or distributions with substrate grain size have done so at relatively localized spatial scales for individual species (e.g. Lindholm et al. 1999). While it is not clear whether juveniles have an obligate relationship with particular substrates, this work has demonstrated reduced predation rates and increased juvenile survivorship in coarser sediments (e.g. Lindholm et al. 1999). However, it has been difficult to link fish distributions in a quantitative manner to substrate types at the broader scales on which marine fish populations and their associated fisheries operate (e.g. DeLong \& Collie 2004). A quantitative broad-scale analysis comparing the relative importance of substrate to that of depth and temperature on the Scotian Shelf concluded that substrate is a poor predictor of species distributions (Mahon \& Smith 1989), but similar relationships in other parts of the NW Atlantic are not well understood on a broad scale. Perhaps the largest barrier to establishing these relationships is the lack of detailed and synoptic information on benthic landscapes.

As fisheries management continues to explore spatial management options (Shipely 2004), it will become increasingly important to evaluate concurrently the multiple factors that delineate fish habitat. Although habitat is thought to be an important component of spatial management, habitat variation is often not quantified when assessing the effectiveness of these approaches in either temperate or tropical systems (e.g. García-Charton \& Pérez-Ruzafa 1999, Murawski et al. 2000). Recent work indicated that spatial management (i.e. area closures) in the NW Atlantic has had mixed success (e.g. Murawski et al. 2000), and other studies have also suggested that the effects of habitat variables may be at least as important as fishing cessation for fish distribution and abundance (e.g. Link et al. 2004).

Our objective was to simultaneously evaluate multiple factors that are suspected to delineate marine fish habitat in the Gulf of Maine-Georges Bank region of the NE US Shelf large marine ecosystem (Sherman et al. 1996). We examined the relative importance of these factors for the distribution and abundance of a 24 species groundfish assemblage and determine whether relative importance changes with season. We then explored how individual species in the assemblage shift their relative distribution along environmental gradients on a seasonal basis.

\section{MATERIALS AND METHODS}

We obtained biomass data $\left(\mathrm{kg} \mathrm{tow}^{-1}\right)$ for 24 common demersal finfish species (Table 1) from the Northeast Fisheries Science Center (NEFSC) bottom trawl survey database (Azarovitz 1981, NEFC 1988). The surveys collect data on a semiannual basis from 350 to 400 sampling stations, approximately 1 per 200 square nautical miles, from Nova Scotia to Cape Hatteras, using a stratified-random sampling design (NEFC 1988). Within each stratum, $2^{\prime}$ latitude $\times 2.5^{\prime}$ longitude rectangular sampling units are randomly selected and each station is sampled using a No. 36 Yankee (or comparable) bottom trawl deployed for $30 \mathrm{~min}$ at a tow speed of $6.5 \mathrm{~km}$ $\mathrm{h}^{-1}$. Several parameters, including the taxonomic identification and biomass of each species, are recorded for each tow. A more detailed description of the bottom trawl sampling design and methodology has been published elsewhere (Azarovitz 1981, NEFC 1988). We examined bottom trawl data from the fall and spring over the temporal extent of 3 roughly decadal timeblocks (1968-1979, 1980-1989, 1990-2002).

We evaluated bottom depth, bottom temperature, and substrate grain size as explanatory environmental variables in the analyses. Bottom temperature and bottom depth data were recorded for each tow of the NEFSC bottom trawl surveys. The substrate data set used in these analyses was based on a surficial sediment database for this region that was assembled by

Table 1 . The 24 species included in the analyses

\begin{tabular}{|ll|}
\hline Scientific name & Common name \\
\hline Sqaulus acanthias & Spiny dogfish \\
Raja laevis & Barndoor skate \\
Raja ocellata & Winter skate \\
Raja erinacea & Little skate \\
Raja radiata & Thorny skate \\
Merluccius bilinearis & Silver hake \\
Gadus morhua & Atlantic cod \\
Melanogrammus aeglefinus & Haddock \\
Pollachius virens & Pollock \\
Urophycis tenuis & White hake \\
Urophycis chuss & Red hake \\
Urophycis regia & Spotted hake \\
Hippoglossoides platessoides & American plaice \\
Paralichthys dentatus & Summer flounder \\
Paralichthys oblongus & Fourspot flounder \\
Limanda ferruginea & Yellowtail flounder \\
Pseudopleuronectes americanus & Winter flounder \\
Glyptocephalus cynoglossus & Witch flounder \\
Scophthalmus aquosus & Windowpane \\
Myoxocephalus octodecemspinos & Longhorn Sculpin \\
Sebastes fasciatus & Acadian redfish \\
Hemitripterus americanus & Sea raven \\
Macrozoarces americanus & Ocean pout \\
Lophius americanus & Goosefish \\
\hline
\end{tabular}


the US Geological Survey (Poppe et al. 2003). This data set is a compilation of numerous surveys carried out by multiple investigators who, in general, employed grab samplers or dredges to collect surficial sediment samples. Time-block was also included in the analysis as a proxy for the effect of fishing pressure on biomass.

To examine relationships between fish biomass and environmental variables in a spatially explicit manner, a grid composed of spatial cells measuring 10' longitude $\times 10^{\prime}$ latitude was overlaid on the region. Each sample or sampling station was assigned to the spatial cell in which it occurred and the mean of each variable
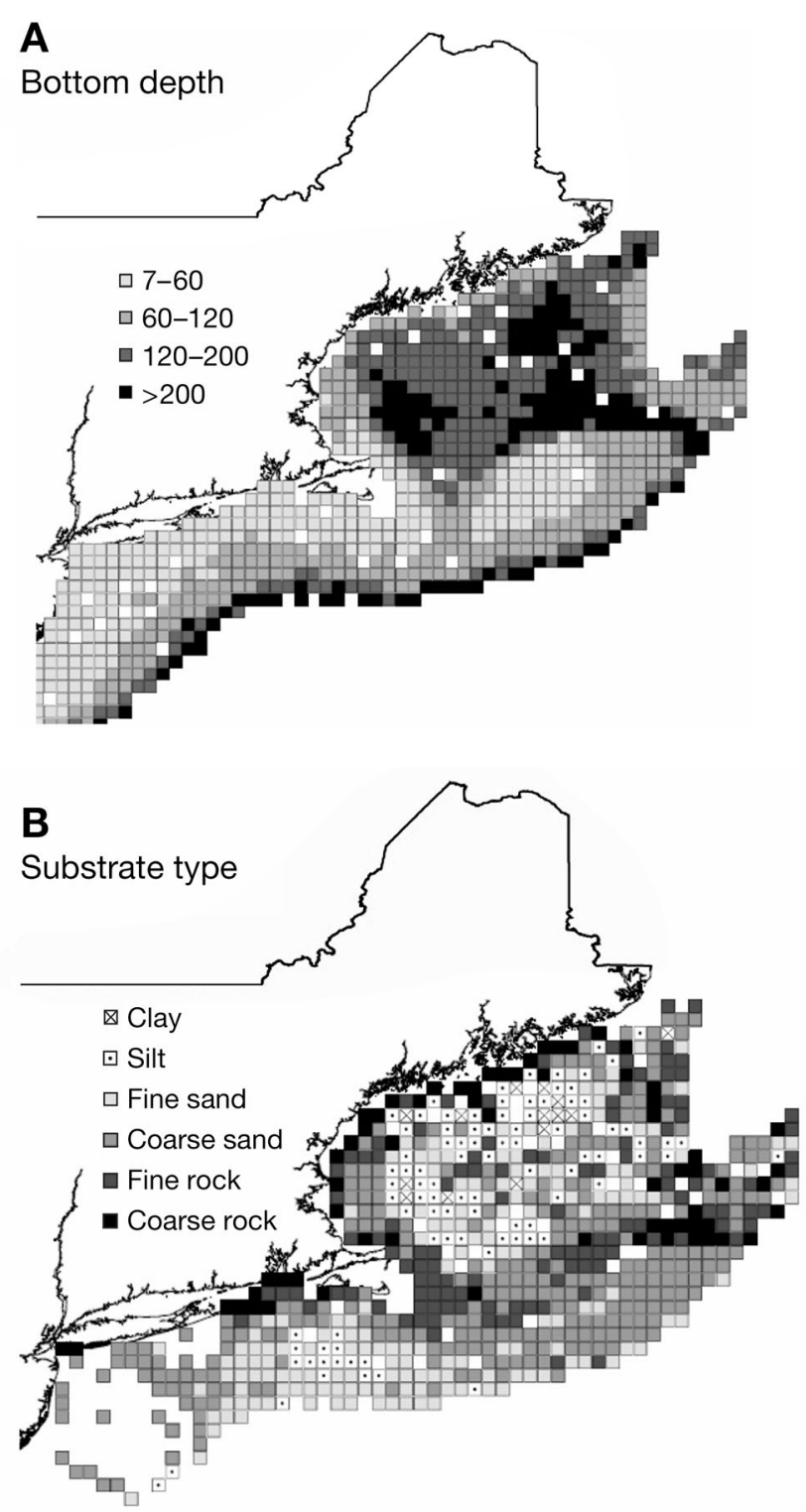

was calculated for each spatial cell. The mean depth, grain size, temperature (Fig. 1), and biomass for the 24 species were then used in the analyses. An average of $9.96 \pm 0.33$ (average $\pm 95 \% \mathrm{CI}$ ) bottom trawl sampling stations occurred in each spatial cell during the 1968 to 2002 time period (Fig. 2). For the sediment data, there were on average $59.19 \pm 17.65$ (average $\pm 95 \% \mathrm{CI}$ ) samples per spatial cell. The spatial extent of the substrate data overlapped with that of the bottom trawl surveys in the Gulf of Maine, on Georges Bank, and in portions of southern New England, so our analyses focused on these regions.
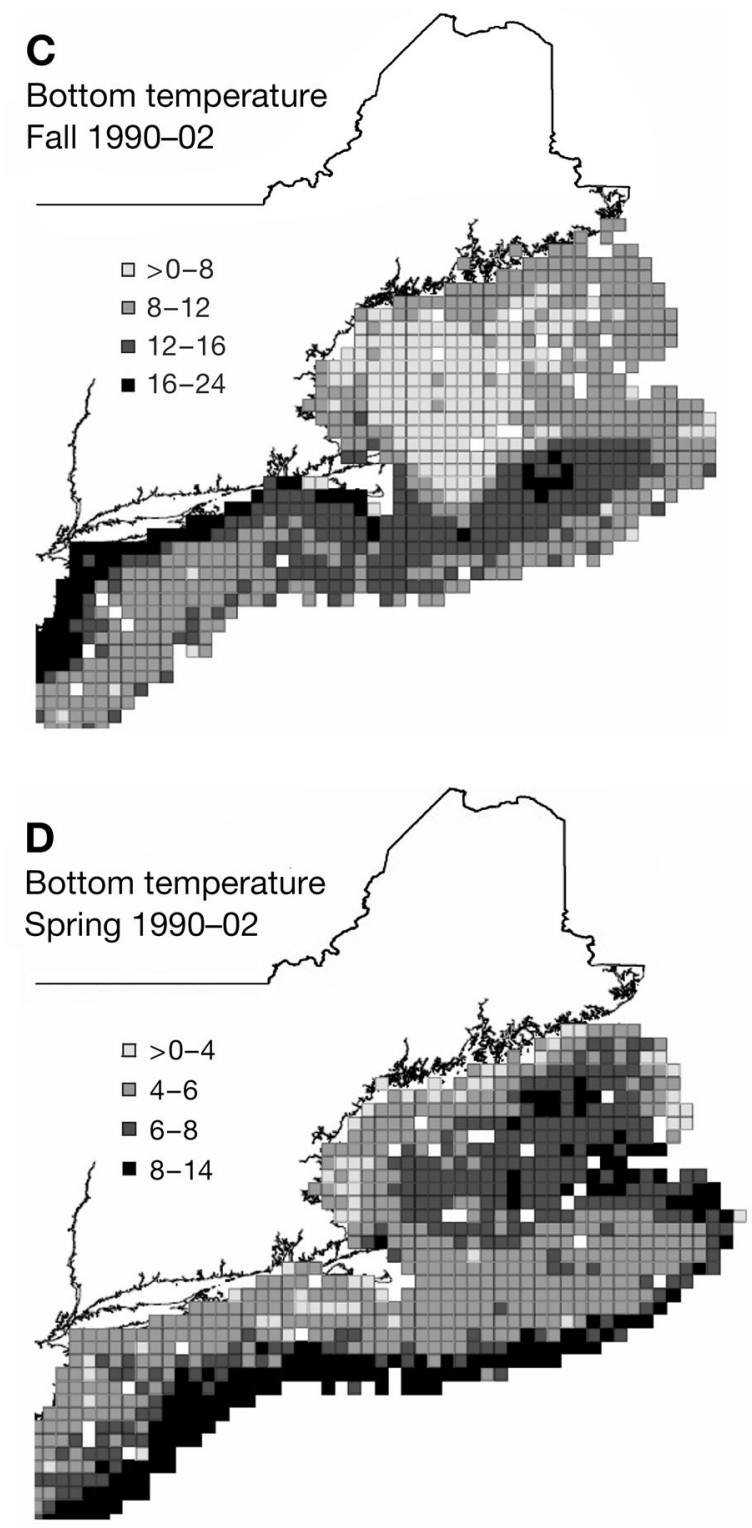

Fig. 1. (A) Average depth (m). (B) Average substrate grain size (mm). Sediment grain size categories were based on the scale of Wentworth (1922): clay, $\leq 0.004 \mathrm{~mm}$; silt, 0.004 to $0.062 \mathrm{~mm}$; fine sand, 0.062 to $0.25 \mathrm{~mm}$; coarse sand, 0.25 to $2.0 \mathrm{~mm}$; fine rock, 2.0 to $8 \mathrm{~mm}$; coarse rock $>8 \mathrm{~mm}$. (C) Average bottom water temperature $\left({ }^{\circ} \mathrm{C}\right.$ ) in the fall for the 1990 to 2002 time-block. (D) Average bottom water temperature $\left({ }^{\circ} \mathrm{C}\right)$ in spring for the 1990 to 2002 time-block. Data are averages for each 10' square spatial cell 

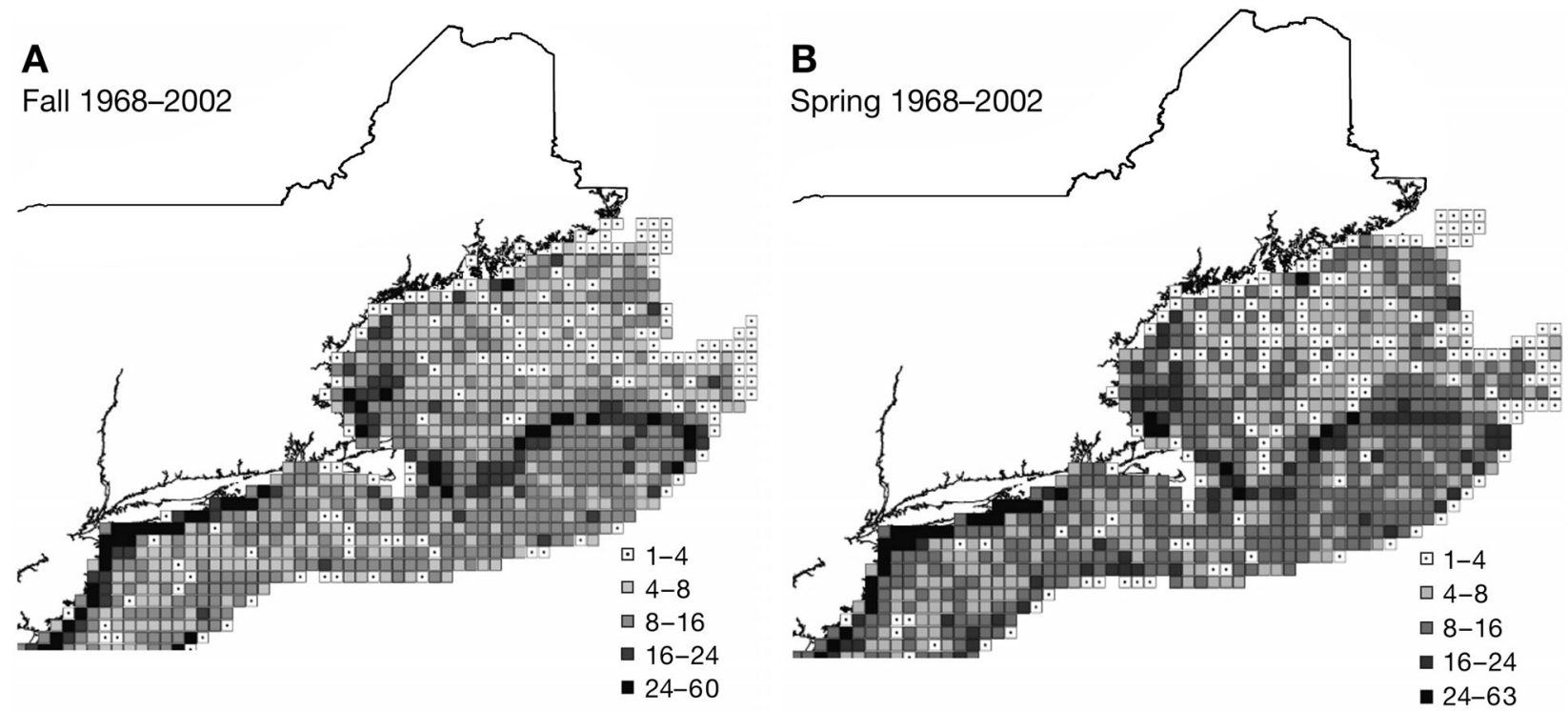

Fig. 2. Number of bottom trawl sampling stations per spatial cell for fall and spring during the time period 1968 to 2002

We employed canonical correspondence analysis (CCA) using CANOCO (ter Braak 1986) to examine the relationships of the fish assemblage with bottom depth, bottom temperature, substrate grain size, season, and time-block. CCA is a commonly used method of direct gradient analysis (ter Braak 1986) that places species along explanatory gradients such that species that are relatively more abundant under a particular set of explanatory conditions are grouped together (ter Braak 1986). To do this, CCA determines a score for each species which is constrained to a linear combination of the explanatory factors in the analysis. The scores are presented in a biplot, which depicts both the species scores and vectors representing the explanatory factors. The length of the vectors on the biplot indicates the magnitude of their relative importance in the ordination. The position and direction of the vectors indicates how they are correlated with each other and with each axis. The relative position of species along the vectors reflects how species are associated with each factor relative to the other species in the ordination. CCA also determines the total amount of inertia or variance explained by the set of explanatory factors. We used partial ordination techniques to determine the percentage of explainable variance attributable to each factor in the CCAs (ter Braak 1986). Note that, because data are aggregated into $10^{\prime}$ spatial cells, the variance attributable to within-cell variation is not captured by the analyses. An advantage of CCA over other methods is that it allows the simultaneous exploration of multi- ple environmental factors and multiple species. For this reason, CCA is a powerful data exploration tool and we used it in this sense.

We carried out a CCA for both fall and spring seasons combined as well as individual CCAs for each fall and spring to examine the seasonal shifts in relative species distributions along environmental and temporal gradients. Species data were square-root transformed prior to each CCA. Analyzing both seasons together permitted us to quantify the relative importance of season for fish distribution compared to other factors. Examining the fall and spring sea-

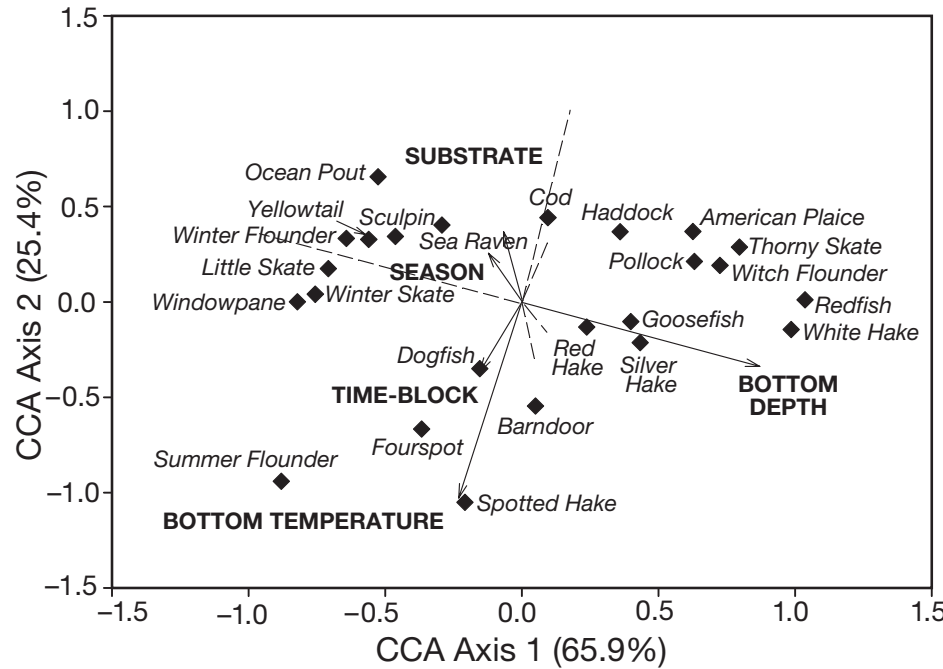

Fig. 3. Canonical correspondence analysis (CCA) examining relationship of fish assemblage with environmental factors; biplot from ordination combining both spring and fall data. See Table 1 for specific names 
sons separately then permitted us to focus on seasonal shifts in biomass along the environmental gradients. To visualize species-habitat relationships, the cumulative distributions for 4 example species were plotted across gradients in bottom depth, bottom temperature, and substrate type for both seasons during the 1968 to 2002 time period.

\section{RESULTS}

In the analysis that combined the fall and spring seasons, $20.95 \%$ of the total variance in species distributions was explained (Fig. 3, Table 2). The first and second CCA axes explained 65.9 and $25.4 \%$ of the explainable variance respectively. Depth explained the ma- jority of the explainable variance in species distribution and was most closely associated with the first canonical axis (Table 2). Bottom temperature was most closely associated with the second canonical axis and ranked second in relative importance (Table 2). Sub-

Table 2. Overall total variance (\%) explained by all variables together and the portion of total variance explained by each individual variable in CCA. Percentage of total explainable variance accounted for by each variable is given in parentheses

\begin{tabular}{|c|c|c|c|c|c|c|}
\hline Factor & \multicolumn{2}{|c|}{ Fall } & \multicolumn{2}{|c|}{ Spring } & \multicolumn{2}{|c|}{$\begin{array}{l}\text { Both seasons } \\
\text { combined }\end{array}$} \\
\hline Total explained & 19.79 & & 26.40 & & 20.95 & \\
\hline Bottom depth & 5.67 & $(28.67)$ & 14.41 & $(54.60)$ & 12.39 & $(59.12)$ \\
\hline Bottom temperature & 3.37 & $(17.02)$ & 6.97 & $(26.40)$ & 4.38 & $(20.86)$ \\
\hline Substrate type & 0.51 & $(2.56)$ & 0.58 & $(2.20)$ & 0.81 & $(3.87)$ \\
\hline Time-block & 1.29 & $(6.53)$ & 1.48 & $(5.60)$ & 1.80 & $(8.60)$ \\
\hline Season & \multicolumn{2}{|c|}{-} & \multicolumn{2}{|c|}{-} & 1.58 & (7.53) \\
\hline
\end{tabular}
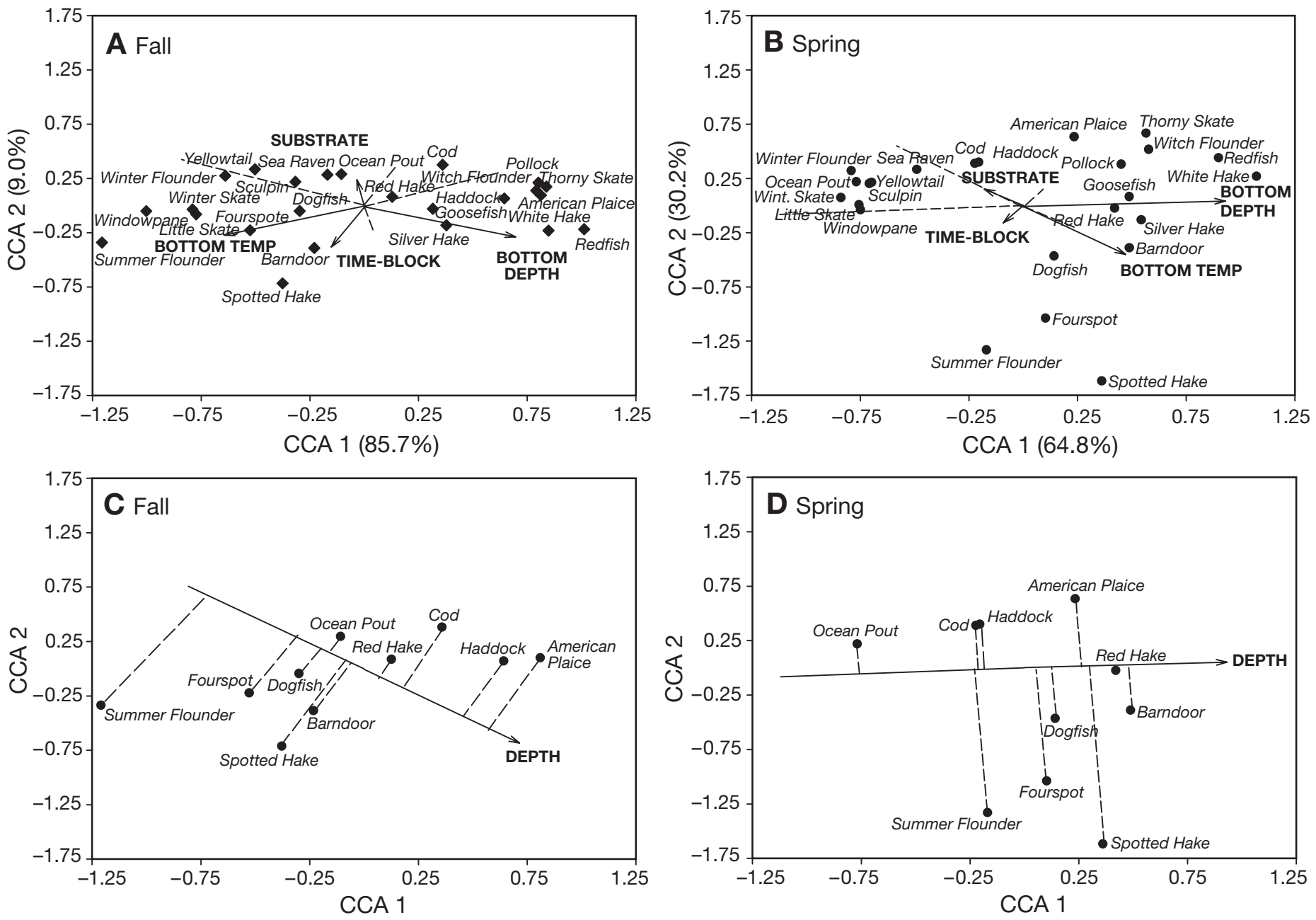

Fig. 4. (A) Fall and (B) spring canonical correspondence analysis (CCA) biplots. (C) Fall and (D) spring vector diagrams for those species that exhibited substantial shifts in their depth distribution with season; diagrams are scaled identically for seasonal comparisons. See Table 1 for specific names 

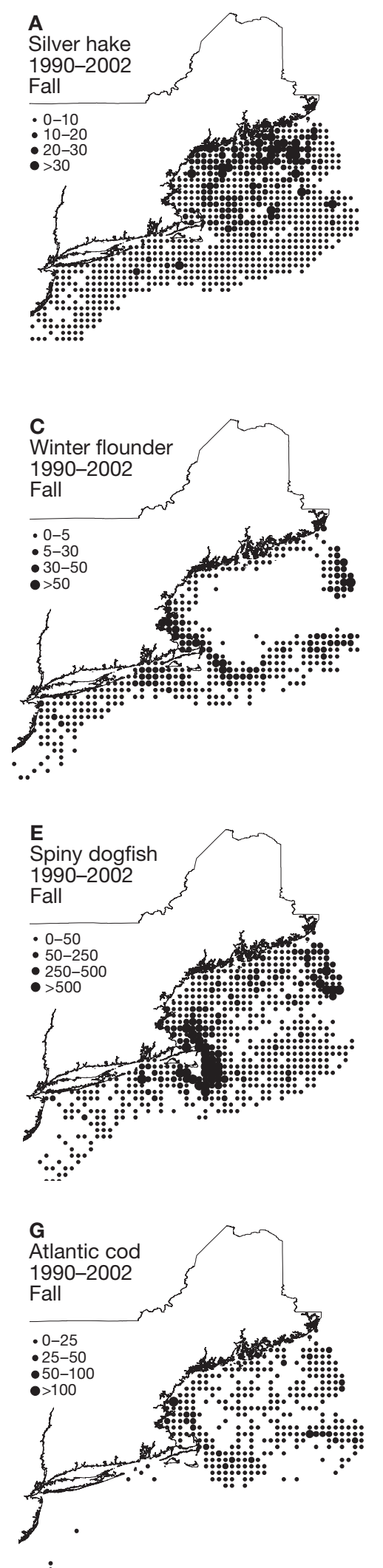

Fig. 5. Fall and spring spatial distributions for representative species during the 1990 to 2002 time-block. Filled circles represent average biomass in each $10^{\prime}$ square spatial cell $\left(\mathrm{kg} \mathrm{tow}^{-1}\right)$. See Table 1 for specific names
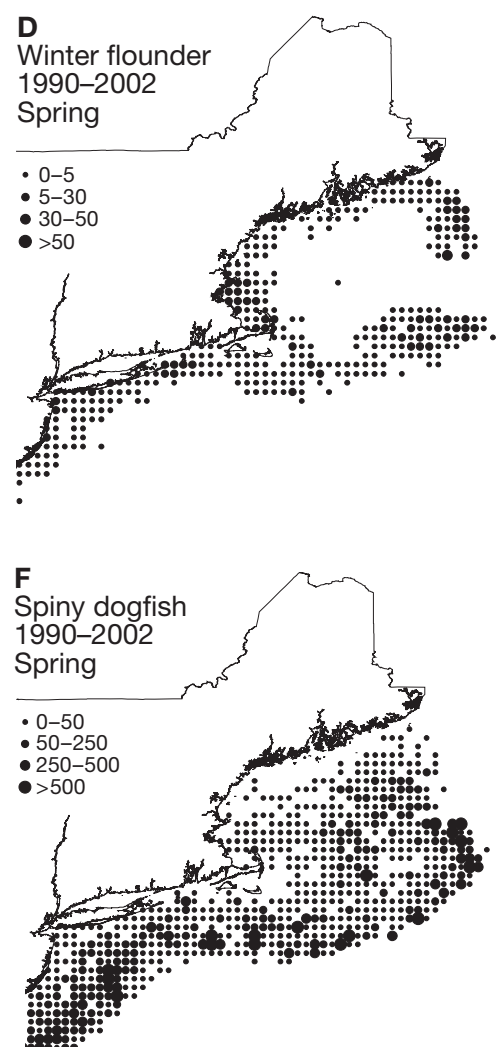
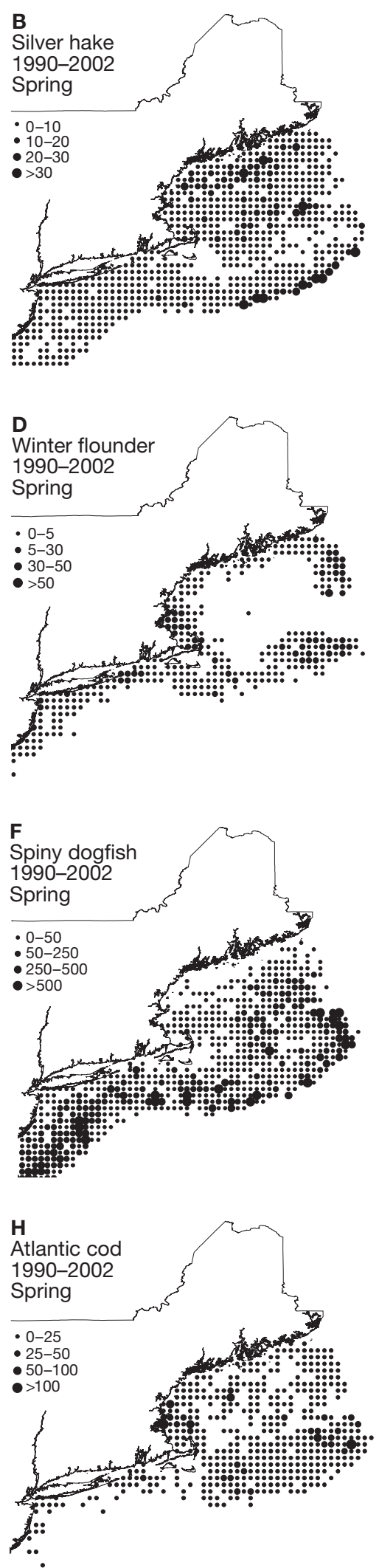

strate type explained the least amount of explainable variance and was associated with the second CCA axis. The 2 temporal factors, season and time-block, were associated with both axes and explained similarly small percentages of explainable variance (Table 2).

Individual season analyses demonstrated that relationships between environmental variables changed with season. During the fall, the depth and temperature vectors were negatively related, indicating that warmer bottom temperatures occurred at shallower depths during this season (Figs. $1 \mathrm{C} \& 4 \mathrm{~A})$. During the spring, depth and temperature were positively related, indicating that deeper waters were relatively warmer than shallower areas during this season. (Figs. 1D \& 4B). Temperatures were also warmer overall in the fall compared to the spring (Fig. 1C,D).

The amount of variance explained by each environmental factor varied with season. Depth, temperature, substrate, and timeblock explained notably less of the total variance in species distributions in the fall compared to spring (Fig. 4A,B, Table 2). The separate fall and spring analyses ranked the relative importance of environmental factors in the same order. Depth was the most important, but the relative importance of depth was much higher in the spring (Fig. 4C,D, Table 2). The first canonical axis explained $85.7 \%$ of the explainable variance in the fall and $64.8 \%$ in the spring (Fig. 4A,B). In both seasons, depth and temperature were both correlated with the first CCA axis (Fig. 4). Similar to depth, temperature was also more important in the spring (Table 2). The second axis explained $9.0 \%$ of the explainable fall variance and $30.20 \%$ of the explainable spring variance. During both seasons, substrate and time-block were associated with the second CCA axis and explained a small proportion of the variance (Table 2). The 'combined' variance, or the variance explained by correlations among factors in the analyses, was much higher in the fall $(45.22 \%)$ than in the spring $(11.20 \%)$ due to generally stronger correlations between depth and temperature in the fall (linear regression, $\mathrm{R}^{2}=0.36,0.20,0.35$ for each time-block respectively) than in the spring (linear regression, $\mathrm{R}^{2}=0.25,0.04,0.26$ for each time-block respectively). 
Four distinguishable patterns emerged from comparison of the fall and spring CCA ordinations (Fig. 4): First, some species remained in relatively deep waters in both fall and spring. This group included white hake, silver hake, Acadian redfish, goosefish, witch flounder, thorny skate, and pollock. By remaining in relatively deep habitats in both seasons, the species in this group experienced the relatively cooler portion of
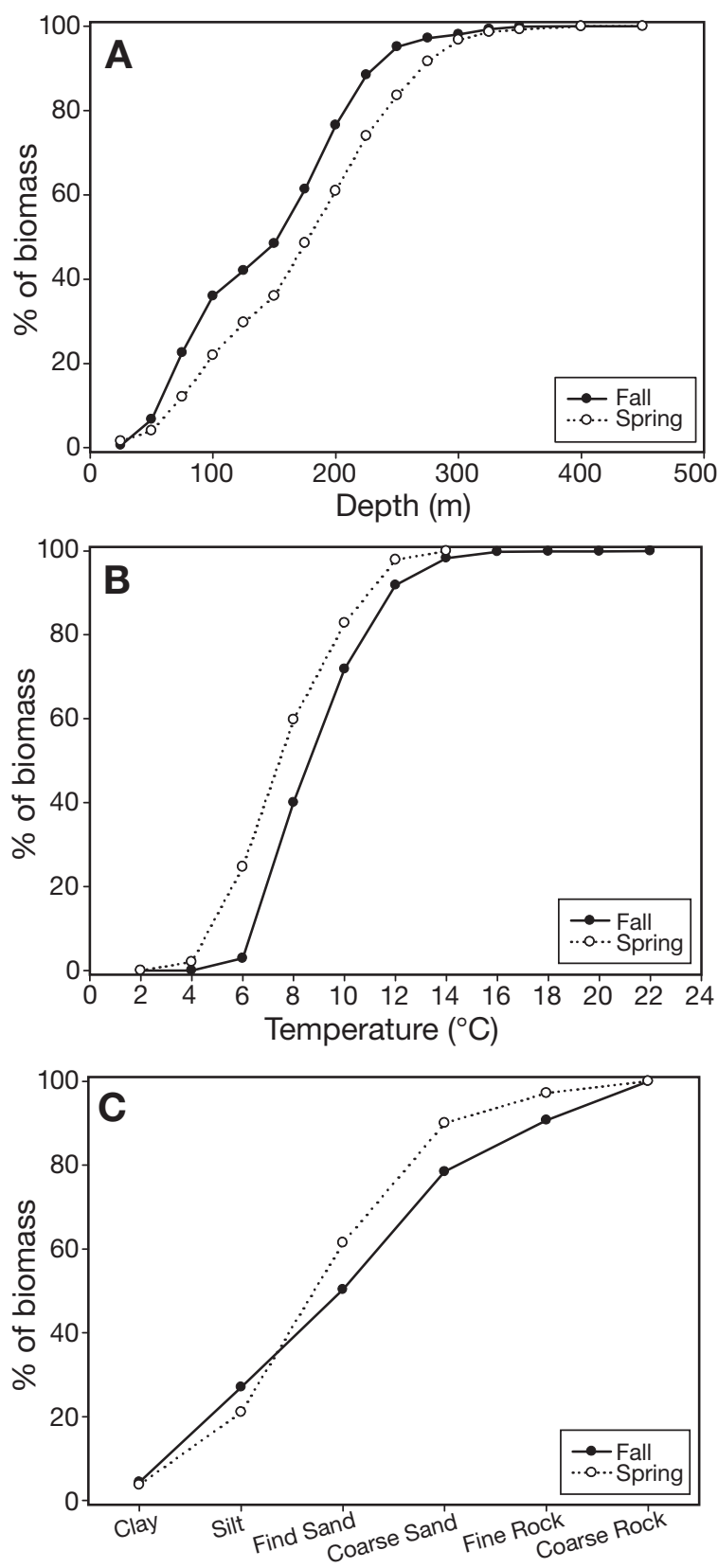

Substrate type

Fig. 6. Merluccius bilinearis. Cumulative distribution plots for silver hake during the fall and spring over gradients in (A) bottom depth, (B) bottom temperature, and (C) substrate type. Cumulative distribution represents data from the 1968 to 2002 time period the region in the fall and the relatively warmer portion of the region in the spring. A representative species from this group, silver hake, was most abundant in portions of the Gulf of Maine in both seasons and also along the southern flank of Georges Bank in the spring where it experienced bottom temperatures between 3 and $15^{\circ} \mathrm{C}$ (Figs. 5A,B \& 6A,B). Bottom temperatures were cooler overall in the spring than in the fall
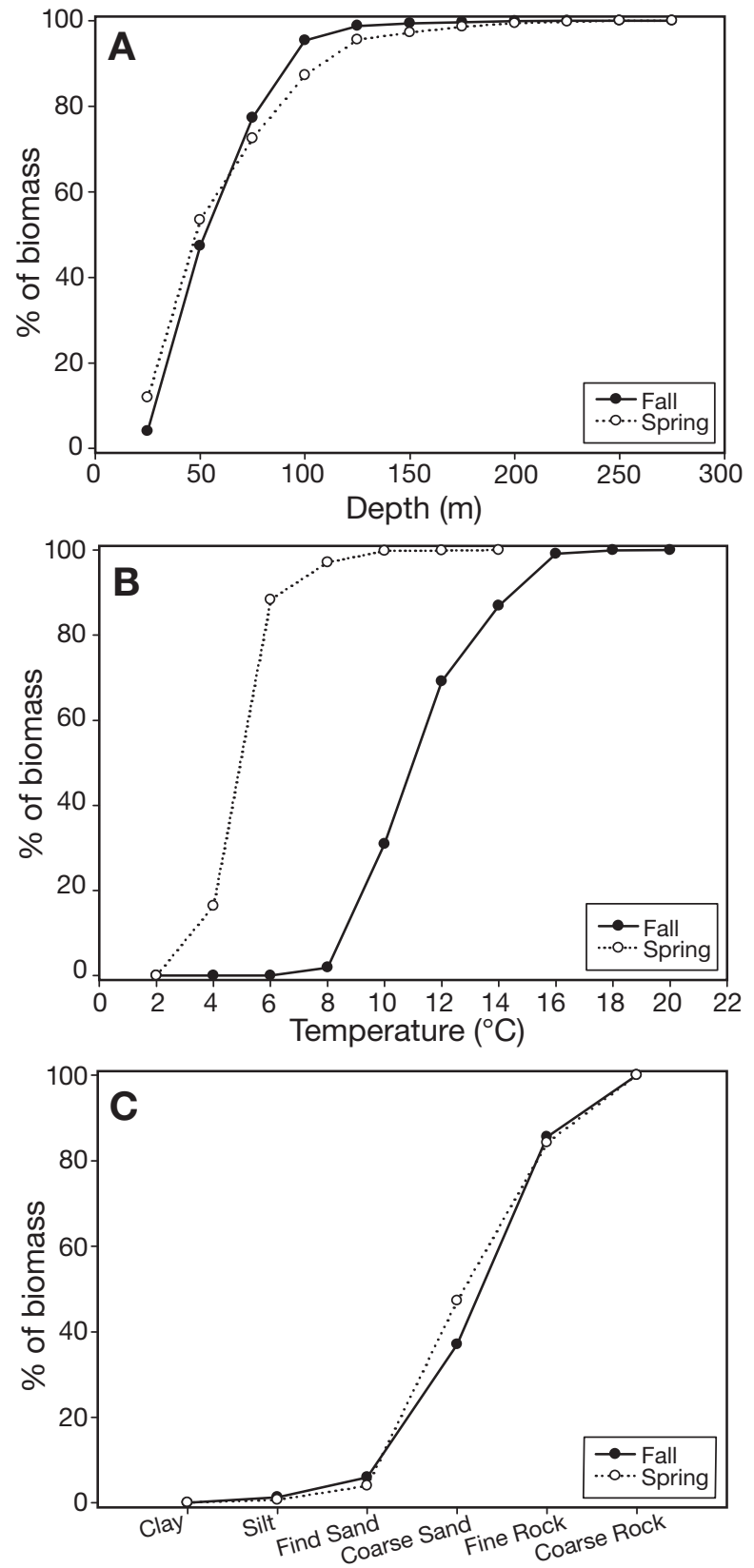

Substrate type

Fig. 7. Pseudopleuronectes americanus. Cumulative distribution plots for winter flounder during the fall and spring over gradients in (A) bottom depth, (B) bottom temperature, and (C) substrate type. Cumulative distribution represents data from the 1968 to 2002 time period 
(Fig. 1C,D). Thus, even though silver hake was associated with some of the warmest temperatures occurring in the region during the spring, these temperatures were still cooler overall compared to those experienced by this species in the fall (Fig. 6B). There was no clear association of silver hake with substrate type (Fig. 6C).

Second, there were some species that remained in relatively shallow habitats in both seasons (Fig. 4). These included winter flounder (Figs. 5C,D \& 7), yellowtail flounder, winter skate, little skate, windowpane, longhorn sculpin, and sea raven. Species that remained in relatively shallow waters in both seasons also experienced wide temperature fluctuations on a seasonal basis, with warmer temperatures in the fall and cooler temperatures in the spring. A representative species from this group, winter flounder, was most abundant in coastal Southern New England and the northern portion of Georges Bank, where it experienced temperatures primarily between 7 and $17^{\circ} \mathrm{C}$ in the fall and between 3 and $8^{\circ} \mathrm{C}$ in the spring (Figs. 7A,B). The position of winter flounder toward the head of the substrate vector and the cumulative distribution plot of winter flounder over substrate types indicated that there was also a trend for this species to be associated with relatively large grain types despite the low amount of variance explained by substrate overall (Figs. 4 \& 7C, Table 2).

Third, some species moved from relatively warm shallow areas in the fall to relatively warm deep areas in the spring (Fig. 4). This group was comprised of spiny dogfish, summer flounder, fourspot flounder, barndoor skate, and red hake. Spiny dogfish, for example, was most abundant in the northern portion of the region during the fall and the more southerly portions of the region during the spring, migrating to maintain a surrounding temperature primarily between 4 and $17^{\circ} \mathrm{C}$ (Figs. 5E,F \& 8A,B). However, temperatures were cooler overall in the spring than in the fall (Fig. 1C,D). Thus, even though spiny dogfish was associated with some of the warmest temperatures occurring in the region during the spring, these temperatures were still cooler overall compared to those experienced by this species in the fall (Figs. 8B). Spiny dogfish was not clearly associated with a particular substrate type but this species was generally more abundant in intermediate size grain types (Fig. 8C).

Fourth, some species traveled from relatively cool deep portions of the region in the fall to relatively cool shallow portions of the range in the spring (Fig. 4). These included Atlantic cod, haddock, American plaice, and ocean pout. As a representative of this group, cod was more abundant around Cape Cod and in the Gulf of Maine during the fall and on Georges Bank during the spring, where it experienced a tem-
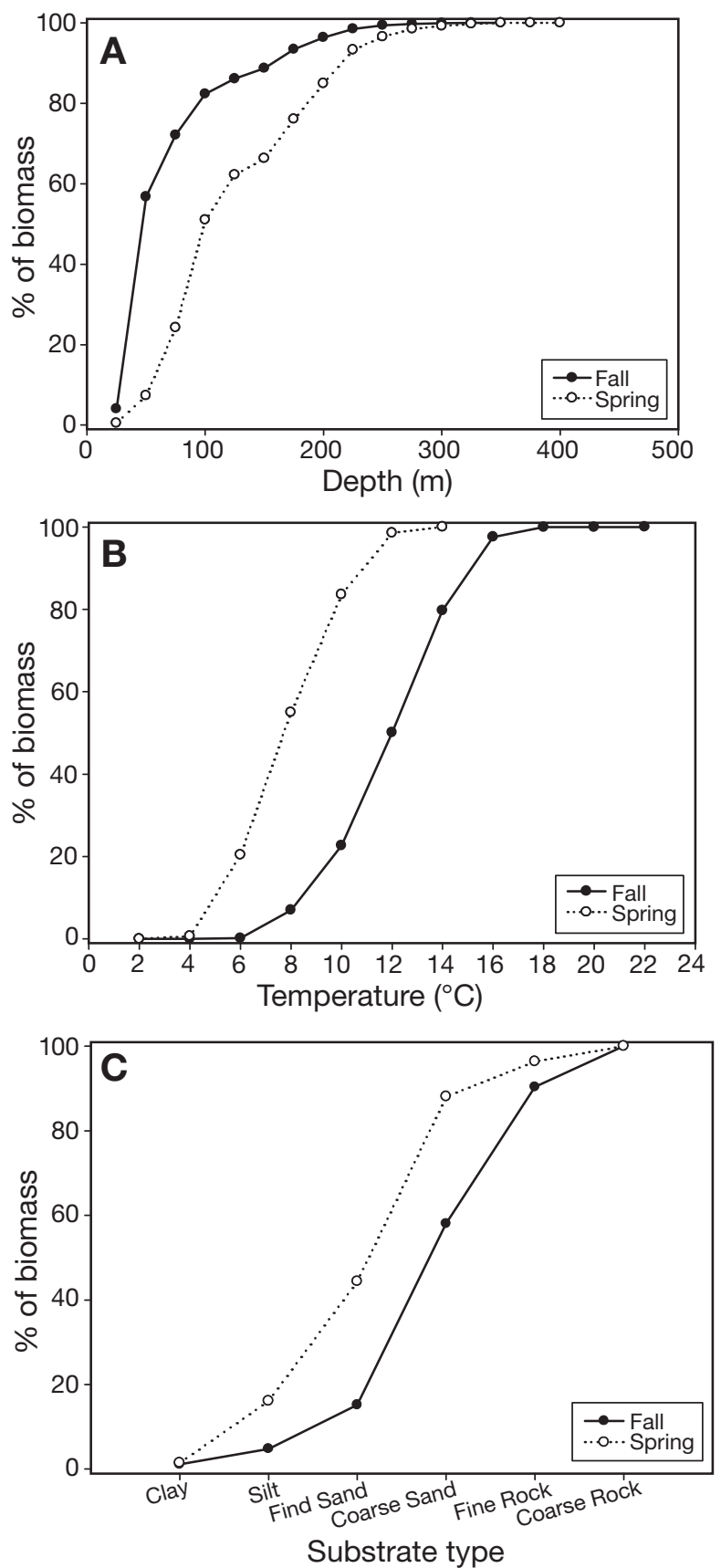

Fig. 8. Squalus acanthias. Cumulative distribution plots for spiny dogfish during the fall and spring over gradients in (A) bottom depth, (B) bottom temperature, and (C) substrate type. Cumulative distribution represents data from the 1968 to 2002 time period

perature range of 3 to $15^{\circ} \mathrm{C}$ (Figs. 5G,H \& 9A,B). Although cod occupied some of the coolest temperatures in the region during the fall, these temperatures were still warmer overall than those experienced by this species in spring due to warmer overall temperatures in the fall compared to spring (Figs. 1C,D \& 9B). The position of cod toward the head of the substrate 

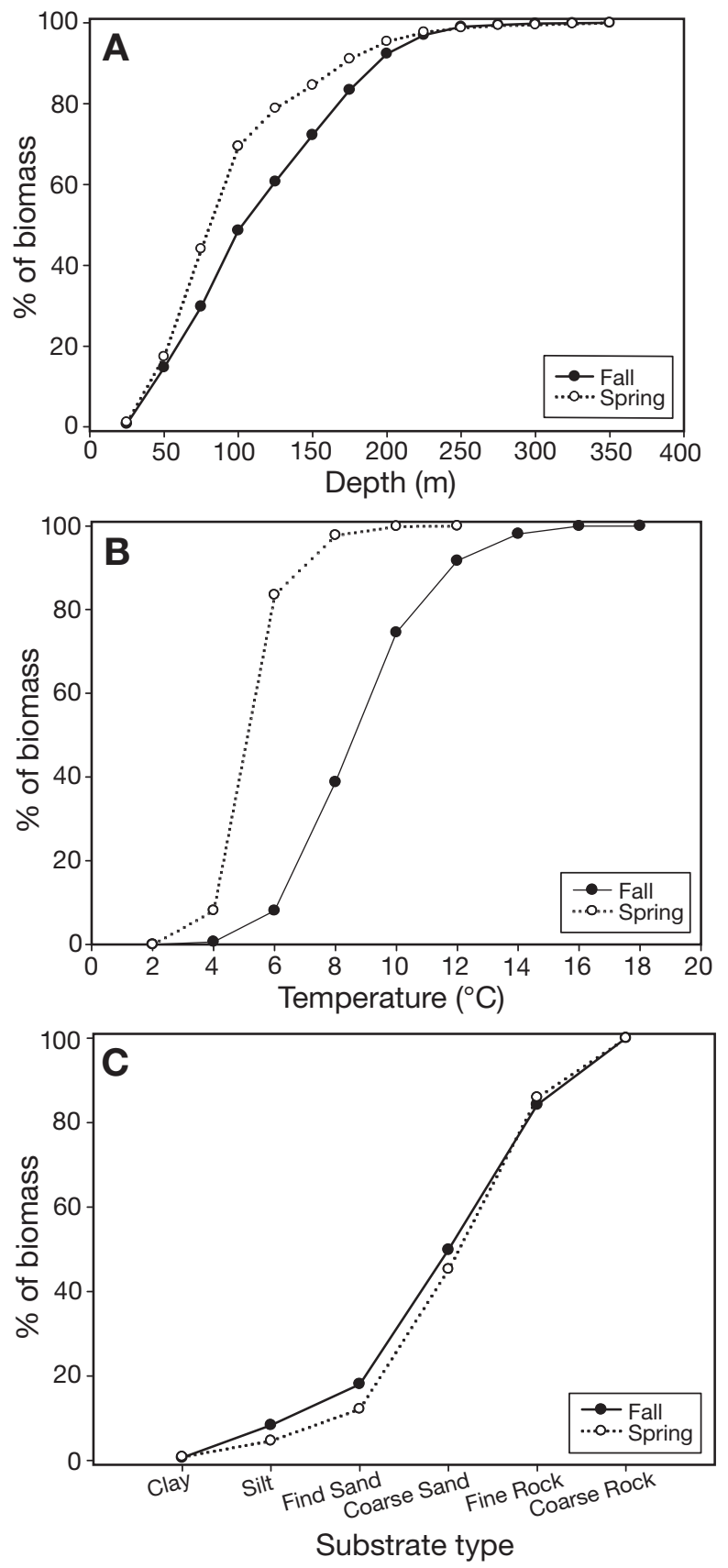

Fig. 9. Gadus morhua. Cumulative distribution plots for Atlantic cod during the fall and spring over gradients in (A) bottom depth, (B) bottom temperature, and (C) substrate type. Cumulative distribution represents data from the 1968 to 2002 time period

vector and the cumulative distribution plot of cod over substrate types indicated that there was a trend for this species to be associated with relatively large sediment grain types despite the small amount of variance explained by substrate overall (Figs. 4 \& 9C).

In both the combined season and individual season CCA ordinations, the time-block vector reflected the temporal change in species biomass (Figs. $3 \& 4$ ). Spiny dogfish, fourspot flounder, summer flounder, spotted hake, and barndoor skate were all relatively more abundant later in the time series. The biomass of the remaining 19 species generally declined over the time series.

\section{DISCUSSION}

\section{Distribution and ecology}

Defining habitat for fish in large temperate marine ecosystems remains a unique challenge. Realized home ranges for temperate species are difficult to assess because of the long distance of seasonal migrations and large daily ambits for many species (Collette \& Klein-MacPhee 2002). Temperate demersal fish utilize multiple habitats on a seasonal as well as a daily basis for numerous ecological reasons (e.g Grosslein \& Azarovitz 1982, Jobling 2002). The high mobility and low site fidelity of many temperate species make it difficult to definitively link these species to their habitat, so detecting even general habitat associations at broad scales is not trivial.

Species distributions are more strongly related to depth and temperature than to substrate type in the Gulf of Maine-Georges Bank region, a pattern similar to that reported for the neighboring Scotian Shelf (Mahon \& Smith 1989). Distributions change on a seasonal basis because of the inextricable relationship between depth, temperature, and season (Drinkwater \& Mountain 1997). Seasonal variation in depth and temperature ranges reflects life history patterns, tolerance for thermal fluctuations, and similar considerations (Murawski \& Finn 1988, Perry \& Smith 1994).

Species that maintained similar depths in the fall and spring in the present study are less sensitive to wide temperature fluctuations and generally do not migrate across a broad depth range to spawn (Collette $\&$ Klein-MacPhee 2002). Although many of the species that were consistently associated with shallow depths in both seasons (e.g. winter flounder, yellowtail flounder, winter skate, little skate, longhorn sculpin, and sea raven) do undergo localized onshore spawning migrations, their maximum depths are still shallower than those of year-round deep-water species. Endurance of wide thermal fluctuations while maintaining depth between seasons indicates that these species are linked to their habitats by other influences such as diet, physiology, behavior, mobility, or inherent swimming ability (e.g. Garrison 2000, Jobling 2002). Our findings for yellowtail flounder and winter flounder are consistent with previous reports from Georges Bank (Murawski \& Finn 1988) and the 
Scotian Shelf (Perry \& Smith 1994) that showed persistence of these species in shallow waters despite dynamic ambient conditions.

Migrations across broad depth ranges are related to temperature sensitivity and life history patterns. Spiny dogfish, summer flounder, fourspot flounder, red hake, spotted hake, and barndoor skate all sought relatively warm surroundings by moving from relatively warm shallow waters in the fall to the relatively warm deep waters in the spring (Grosslein \& Azarovitz 1982, Murawski \& Finn 1988, Collette \& Klein-MacPhee 2002). In addition to their temperature sensitivity, summer flounder, fourspot flounder, and red hake undergo seasonal migrations to onshore spawning grounds (Grosslein \& Azarovitz 1982, Collette \& Klein-MacPhee 2002). Spawning is thought to occur offshore from fall until early spring for spotted hake (Colton et al. 1979) and across the entire range for barndoor skate (Collette \& Klein-MacPhee 2002). Temperature sensitivity also drives north-south seasonal migrations for spiny dogfish (Collette \& Klein-MacPhee 2002). Additionally, spiny dogfish track warmer waters onshore during the fall and offshore during the spring (Collette \& KleinMacPhee 2002).

Migrations from relatively deep cool habitats in the fall to relatively cool shallow habitats in the spring are also related to thermal preferences and life history. Cod, haddock, American plaice, and ocean pout all exhibited this pattern. Movement of cod and haddock to shallow onshore, spring spawning regions is well established (e.g. Collette \& Klein-MacPhee 2002). Although American plaice is generally regarded as a sedentary species, localized movements into shallow waters for spawning (Colton 1972) and in response to temperature change (Powles 1965) have been reported. Similarly, ocean pout is also regarded as relatively sedentary, but this species may undergo localized migrations into cool, shallow water to spawn in the summer and fall (Orach-Meza 1975). The underlying preference by ocean pout for water temperatures ranging from 6 to $9^{\circ} \mathrm{C}$ are also likely to influence this pattern (Collette \& Klein-MacPhee 2002). The general association of cod with larger substrate types reflects seasonal spawning patterns and the preferential use by adults and juveniles gadids of rockier areas known to be nursery grounds (e.g. Lindholm et al. 1999). Our findings are consistent with cod associations with environmental variables on the Scotian Shelf and in the Gulf of Maine (Perry \& Smith 1994, DeLong \& Collie 2004). Murawski \& Finn (1988), however, found that cod and haddock maintained a constant depth with season on Georges Bank. This contrast with our results is likely due to the broader spatial extent and thus longer depth gradient encompassed by our study.

\section{Implications for habitat delineation in temperate systems}

Most of the theory and applied methodologies for spatial fisheries management are derived from tropical coral reef systems (e.g. Shipely 2004). However, there are a number of key differences that distinguish temperate from tropical systems which necessitate modified approaches when applying analogous spatial management methods in large temperate continental shelf systems. In the tropics, the vertical distribution of reef fish is influenced by physiographic factors and reef zonation (Sale 1980). Such close association with a hermatypic reef system limits the maximum habitable depth of tropical reef species and increases overall site fidelity. Temperate demersal fish, in contrast, have relatively large home ranges and many undergo largescale seasonal migrations (e.g. Collette \& KleinMacPhee 2002). The thermal environment of the tropics is also much more stable over vertical, horizontal, and seasonal gradients compared to temperate systems. Additionally, substrate variability is comparatively high and logistically more straightforward to quantify on tropical reefs (Marshall 1985). Lower variability in temperature and depth combined with variable benthic substrates and human impact on coral reefs have led to an emphasis on substrate type in definitions of tropical fish habitat.

Recent work on temperate coastal rocky reefs and temperate kelp forests has also sought to delineate fish-habitat associations. Similar to their analogs on tropical reefs, these studies have tended to focus on species that have small home ranges and high site fidelity (e.g. rockfish, kelp bass) in order to evaluate their appropriateness for spatial management. Accordingly, some of these studies have found notably strong associations (e.g. Lowe et al. 2003), yet statistically rigorous studies have reported that habitat type accounts for only a small amount of variation in fish densities in coastal temperate systems (Paddack \& Estes 2000).

Fish in large temperate systems such as the Gulf of Maine-Georges Bank region are primarily distributed according to depth and temperature (Overholtz \& Tyler 1985, Murawski \& Finn 1988, Gabriel 1992, Perry \& Smith 1994, DeLong \& Collie 2004). The relationships with substrate type demonstrated at local scales for some species (e.g. Lindholm et al. 1999) are weak at more synoptic scales compared to other variables in a multi-species context (Overholtz \& Tyler 1985, Mahon \& Smith 1989). However, the recent application of single-species modeling approaches has demonstrated habitat associations for a few species in the Gulf of Maine (DeLong \& Collie 2004). The paucity of comprehensive detailed information on 
benthic landscapes has been an impediment to establishing species-habitat relationships on a regional basis in both single and multi-species models. In addition to sediment grain size, little is known in a synoptic sense about other sea-bottom attributes such as biogenic structures, wave forms, and burrows that may influence distribution patterns (e.g. Auster et al. 1995, 2003). Increased knowledge of habitats and an integration of this information across spatial scales would be helpful. More clearly delineated habitat associations and an understanding of how these relationships respond to disturbance are essential for spatial management approaches.

Ongoing fishing pressure necessitates precautionary approaches for fisheries management (Lauck et al. 1998). This is illustrated by the reduction in biomass of many target species over time (Link \& Brodziak 2002) coupled with the large amount of variance remaining to be explained in the spatial distributions of many of these species. The documented impact of disturbance to benthic substrates must also be taken into consideration for both fish populations and their habitats (e.g. Kaiser \& de Groot 2000). Of the factors considered in the present analysis, substrate grain size is arguably the factor that is most directly impacted by human actions through the use of mobile, bottom-tending gears (e.g. Dernie et al. 2003). Recovery from disturbance takes longest for the more complex substrates that provide a nursery habitat for some species (e.g. Dernie et al. 2003). The use of essential fish habitat, marine protected area, area closures, and similar spatial management approaches for temperate demersal fish can all mitigate such disturbances to physical habitats (Lindholm et al. 2004). Even for species that are not tightly linked to substrate characteristics, area closures can still prevent the removal of some amount of biomass, serve as mortality refugia (even if only seasonally), and may provide potential source populations. Thus, despite the lack of the strong direct benefits seen in the tropics (Roberts et al. 2001), spatial management approaches are important tools for fisheries management in temperate regions from a precautionary perspective (Shipely 2004).

It is evident that the relationship between temperate demersal fish and bottom types is not as definitive as it appears to be in tropical marine ecosystems. However, assemblage-level analyses may obscure size or age class linkages to benthic habitat features. For those species that occupy broad ranges in habitat gradients, it is still not clear whether particular habitats are more beneficial than others with regard to vital population rates. Although the explanatory power of our analysis is comparable to that of previous studies (e.g. Overholtz \& Tyler 1985), there still remains a considerable proportion of unexplained variance in the distribution of groundfish species. Several factors, including the spatial distribution of fishing pressure, hydrodynamic variables, recruitment rates, and variable prey fields, may play key roles and warrant further examination.

Acknowledgements. We acknowledge the efforts of all those at the NEFSC who have contributed to the planning and execution of the bottom trawl surveys. We thank the NEFSC staff for their dedicated work in auditing and maintaining the bottom trawl survey database. We also thank Mike Fogarty, Larry Jacobsen, and 3 anonymous reviewers for their insightful comments on earlier drafts of this manuscript. This work was supported in part by a postdoctoral research associateship awarded by the National Research Council (USA) to E.M.

\section{LITERATURE CITED}

Auster PJ, Malatesta RJ, LaRosa SC (1995) Patterns of microhabitat utilization by mobile megafauna on the southern New England (USA) continental shelf and slope. Mar Ecol Prog Ser 127:77-85

Auster PJ, Lindholm J, Schaub S, Funnell G, Kaufman LS, Valentine PC (2003) Use of sand wave habitats by silver hake. J Fish Biol 62:143-152

Azarovitz TR (1981) A brief historical review of the Woods Hole Laboratory trawl survey time series. Can Spec Publ Fish Aquat Sci 58:62-67

Collette B, Klein-MacPhee G (eds) (2002) Bigelow and Schroeder's fishes of the Gulf of Maine, 3rd edn. Smithsonian Institution Press, Washington, DC

Colton JB Jr (1972) Temperature trends and the distribution of groundfish in the continental shelf waters, Nova Scotia to Long Island. US Fish Wildl Serv Fish Bull 70:637-657

Colton JB, Smith WG, Kendall AW, Berrien DL, Fahay MP (1979) Principal spawning areas and times of marine fishes, Cape Sable to Cape Hatteras. Fish Bull 76:911-915

DeLong AK, Collie JS (2004) Defining essential fish habitat: a model-based approach. Rhode Island Sea Grant, Narragansett, RI

Dernie KM, Kaiser MJ, Warwick RM (2003) Recovery rates of benthic communities following physical disturbance. J Anim Ecol 72:1043-1056

Drinkwater KF, Mountain DG (1997) Climate and oceanography. In: Boreman J, Nakashima BS, Wilson JA, Kendall RL (eds) Northwest Atlantic groundfish: perspectives on a fishery collapse. American Fisheries Society, Bethesda, MD, p 3-25

Gabriel WL (1992) Persistence of demersal fish assemblages between Cape Hatteras and Nova Scotia, Northwest Atlantic. J Northwest Atl Fish Sci 14:29-46

Garcia-Charton JA, Pérez-Ruzafa A (1999) Ecological heterogeneity and the evaluation of the effects of marine reserves. Fish Res 42:1-20

Garrison, LP (2000) Spatial and dietary overlap in the Georges Bank groundfish community. Can J Fish Aquat Sci 57: 1679-1691

Grosslein MD, Azarovitz TR (1982) Fish distribution. MESA New York Bight Atlas Monogr 15. Marine Ecosystem Analysis (MESA) Program. New York Sea Grant Institute, Albany, NY

Jobling M (2002) Environmental factors and rates of development and growth. In: Hart PJB, Reynolds JD (eds) Handbook of fish biology and fisheries. Blackwell Science, Malden, MA, p 97-122 
Kaiser MJ, de Groot SJ (2000) Effects of fishing on non-target species and habitats. Blackwell Science, Oxford

Lauck T, Clark CW, Mangel M, Munro GR (1998) Implementing the precautionary principle in fisheries management through marine reserves. Ecol Appl 8(Suppl): S72-S78

Lindholm JB, Auster PJ, Kaufman LS (1999) Habitat-mediated survivorship of juvenile (0-year) Atlantic cod Gadus morhua. Mar Ecol Prog Ser 180:247-255

Lindholm J, Auster P, Valentine P (2004) Role of large marine protected area for conserving landscape attributes of sand habitats on Georges Bank (NW Atlantic). Mar Ecol Prog Ser 269:61-68

Link J, Brodziak J (2002) Report on the status of the NE US Continental Shelf ecosystem. NEFSC Ecosystem Status Working Group. Northeast Fisheries Science Center Ref Doc 02-11. p 1-245

Link JS, Almeida F, Valentine P, Auster P, Reid R, Vitaliano J (2005) The effect of area closures on Georges Bank. Am Fish Soc Symp 41:345-368

Lowe CG, Topping DT, Cartamil DP, Papastamatiou YP (2003) Movement patterns, home range, and habitat utilization of adult kelp bass Paralabrax clathratus in a temperate notake marine reserve. Mar Ecol Prog Ser 256:205-216

Mahon RR, Smith RW (1989) Demersal fish assemblages on the Scotian shelf, northwest Atlantic: spatial distribution and persistence. Can J Fish Aquat Sci 46:134-152

Marshall N (1985) Ecological sustainable yield (fisheries potential) of coral reef areas, as related to physiographic features of coral reef environments. Proc 5th Int Coral Reef Congr 5:525-530

Murawski SA, Finn JT (1988) Biological basis for mixed-species fisheries: species codistribution in relation to environmental and biotic variables. Can J Fish Aquat Sci 45:1720-1735

Murawski SA, Brown R, Lai HL, Rago PJ, Hendrickson L (2000) Large-scale closed areas as a fishery management tool in temperate marine systems: the Georges Bank experience. Bull Mar Sci 66:775-798

NEFC (Northeast Fisheries Science Center) (1988) An evaluation of the bottom trawl survey program of the Northeast

Editorial responsibility: Kenneth Sherman (Contributing Editor), Narragansett, Rhode Island, USA
Fisheries Science Center. NOAA Tech Memo NMFS F/NEC-52

Orach-Meza FL (1975) Distribution and abundance of ocean pout, Macrozoarces americanus (Bloch and Schneider) 1801 in the western North Atlantic Ocean. MS thesis, University of Rhode Island, Kingston, RI

Overholtz WJ, Tyler AV (1985) Longterm responses of the demersal fish assemblages of Georges Bank. US Fish Wildl Serv Fish Bull 83:507-520

Paddack MJ, Estes JA (2000) Kelp forest fish populations in marine reserves and adjacent exploited areas of central California. Ecol Appl 10:855-870

Perry RI, Smith SJ (1994) Identifying habitat associations of marine fishes using survey data: an application to the Northwest Atlantic. Can J Fish Aquat Sci 51:589-602

Poppe LJ, Paskevich VF, Williams SJ, Hastings ME and 5 others (2003) Surficial sediment data from the Gulf of Maine, Georges Bank, and vicinity: a GIS compilation. US Geological Survey Open-File Rep 03-001. Available online at: http://pubs.usgs.gov/of/2003/of03-001/ index.htm

Powles PM (1965) Life history and ecology of American plaice (Hippoglossoides platessoides F.) in the Magdalen Shallows. J Fish Res Board Can 22:565-598

Roberts CM, Bohnsack JA, Gell F, Hawkins JP, Goodridge R (2001) Effects of marine reserves on adjacent fisheries. Science 294:1920-1923

Sale PF (1980) The ecology of fishes on coral reefs. Oceanogr Mar Biol Annu Rev 18:367-421

Sherman K, Jaworski NA, Smayda TJ (1996) The Northeast Shelf ecosystem-assessment, sustainability, and management. Blackwell Science, Cambridge

Shipley JB (ed) (2004) Aquatic protected areas as fisheries management tools. Am Fish Soc Symp 42

ter Braak CJF (1986) Canonical correspondence analysis: a new eigenvector method for multivariate direct gradient analysis. Ecology 67:1167-1179

Wentworth CK (1922) A scale of grade and class terms for clastic sediments. J Geol 30:377-392

Submitted: March 22, 2005; Accepted: April 10, 2006

Proofs received from author(s): November 6, 2006 